\title{
Exploring the Concepts of Abuse and Neglect of Children in Victorian Novel: A Revisitation of Dickens' Works
}

\author{
Ibrahim YEKINI, \\ ENS, University of Abomey Calavi (Rep. Benin) \\ Corresponding authors: Ibrahim YEKINI; adebiaye20@gmail.com
}

Received 23 August 2019;

Accepted 01 September 2019;

Published 16 September 2019

\begin{abstract}
The long term abuse of children, physically, emotionally, sexually or through neglect can have major long-term effects on all aspects of a child's health, development and well-being. This emotional violence is likely to have a deep impact on the child's self-image and self-esteem, and on his or her future life. This article is a critical exploration of Charles Dickens' novels, Oliver Twist and David Copperfield that has been slightly adapted from my doctoral dissertation, to pinpoint aspects of moral and physical violence Victorian children are exposed to during the Industrial Revolution in England, in order to examine its impacts on their emotional development and make suggestions for a sustained solutions to the same plights devastating African children.
\end{abstract}

Keywords: abuse-neglect-children-Victorian novel-Industrial Revolution

\section{Introduction}

Any potentially abusive incident has to be seen in its context to assess the extent of harm to a child in order to identify appropriate interventions. Often, it is the interaction between a number of factors that serve to increase the likelihood or level of actual significant harm. For every child and family, there may be factors that aggravate the harm caused to the child, and those that protect against harm. Relevant factors include the individual child's means of coping and adapting, support from a family and social network, and the impact of any interventions. Children are rightly considered as the continuators of the strict social conducts their parents imposed on the families, which brought hostile relationships with future households, as illustrated by Oliver in Oliver Twist.1 The effects on a child are also influenced by the quality of the family environment at the time of abuse, and subsequent life events. An important point, sometimes overlooked, is that the way in which professionals respond has a significant bearing on subsequent outcomes. Somebody may abuse or neglect a child by inflicting harm, or by failing to act to prevent harm. The Industrial Revolution in the 19th century offers a perfect setting for the description of the problem under the lens of the Victorian novel, consequently geo-criticism, social criticism and historicism are slightly used in this article for the critical analysis.

\section{1-Physical Abuse}

Physical abuse may involve hitting, shaking, throwing, poisoning, burning or scalding, drowning, suffocating, or otherwise causing physical harm to a child. Physical harm may also be caused when a parent or any adult induces illness in a child whom they are looking after. Physical abuse can lead directly to neurological damage, physical injuries, disability or - at the extreme - death. Little Oliver in.

Oliver Twist was nearly dead of hunger in the orphanage. Harm may be caused to children both by the abuse itself and by the abuse taking place in a wider family or institutional context of conflict and aggression. Physical abuse has been linked to aggressive behaviour in children, emotional and behavioural problems, and educational difficulties. Violence is pervasive and the physical abuse of children frequently coexists with domestic abuse, both aspects are illustrated in Dickens'

\section{2-Emotional Abuse}

Emotional abuse is the persistent emotional ill-treatment of a child such as to cause severe and persistent adverse effects on the child's emotional development. It may involve conveying to children that they are worthless or unloved, inadequate, or valued only insofar as they meet the needs of another person. It may feature age or developmentally inappropriate expectations being imposed on children. It may involve causing children frequently to feel frightened or in danger, or the exploitation or corruption of children. Some level of emotional abuse is involved in all types of ill-treatment of a child, though it may occur alone. There is increasing evidence of the adverse long-term consequences for children's development where they have been subject to sustained emotional abuse.

Emotional abuse has an important impact on a developing child's mental health, behaviour and self-esteem. It can be 
especially damaging in infancy. Underlying emotional abuse may be as important, if not more so, than other more visible forms of abuse in terms of its impact on the child. Domestic abuse, adult mental health problems and parental substance misuse may be features in families where children are exposed to such abuse.

\section{3-Sexual Abuse}

Sexual abuse involves raping or motivating a child or young person to take part in sexual activities, whether or not the child is aware of what is happening. The activities may involve physical contact, including penetrative or non-penetrative acts. They may include non-contact activities, such as involving children in looking at, or in the production of, pornographic material or watching sexual activities, or encouraging children to behave in sexually inappropriate ways. Disturbed behaviour including self-harm, inappropriate sexualized behaviour, depression and a loss of selfesteem, have all been linked to sexual abuse. Its adverse effects may endure into adulthood. The severity of impact on a child is believed to increase the longer abuse continues, the more extensive the abuse, and the older the child. A number of features of sexual abuse have also been linked with severity of impact, including the relationship of the abuser to the child, the extent of premeditation, the degree of threat and coercion, sadism, and unusual elements. A child's ability to cope with the experience of sexual abuse, once recognised or disclosed, is strengthened by the support of a nonabusive adult carer who believes the child, helps the child understand the abuse, and is able to offer help and protection. The reactions of practitioners also have an impact on the child's ability to cope with what has happened, and his or her feelings of selfworth. A proportion of adults who sexually abuse children have themselves been sexually abused as children. They may also have been exposed as children to domestic abuse and discontinuity of care. Sexual abuse on children can have an impact on future relationships and a proportion of children who have been sexually abused may go on to sexually abuse children themselves. However, it would be quite wrong to suggest that most children who are sexually abused will inevitably go on to become abusers themselves.

\section{4-Domestic Abuse}

When a child witnesses domestic abuse, this can have a substantial damaging effect upon the development of a child. Even if the child does not itself suffer from the abuse directly, the long term effects of witnessing physical and/or emotional abuse can be significant. In addition the parent or carer who is subject to domestic abuse might have reduced parenting ability and this will have an effect upon the Child.

Prolonged and/or regular exposure to domestic abuse can have a serious impact on a child's development, psychological and emotional well-being, despite the best efforts of the victim parent to protect the child. Domestic abuse has an impact in a number of ways. It can pose a threat to an unborn child, because assaults on pregnant women frequently involve punches or kicks directed at the abdomen, risking injury to both mother and fetus. Children may also suffer blows during episodes of violence. Children may be greatly distressed by witnessing the physical and emotional suffering of a parent'. Domestic abuse (both physical and psychological) can have a negative impact upon the victim's ability to look after their children.

Children's exposure to parental conflict, even when violence is not present, is upsetting and can lead to serious anxiety and longerterm psychological distress. Children may witness or be drawn into the abuse, or pressurised into concealing it, which further exacerbates the damaging effect. Substance misuse can also be a contributing factor adding to the serious impact of domestic abuse.

\section{5-Economic Exploitation}

Children were expected to help supplement the family budget and were sent to work quite young. These weren't gentile jobs, they were manual labour paying extremely low wages. Factories employed the young to crawl beneath huge machinery - into spaces which adults were too large to enter. Long hours of drudgery would be the order of the day, often starting before dawn and continuing after dark. Conditions were unsafe. Children who crawled beneath working machines were often killed. Coal mines wanted children to open and close ventilating doors. Until the middle of the 1800 's, children as young as five would often work up to 12 hours a day underground, often barefoot.

If not employed in a business, youngsters would roam the streets looking for work. Being a messenger was a 'clean' job, as was selling flowers. Others would polish shoes, sweep front steps, or become chimney sweeps. Some poorer Victorian children found that criminal activities made their lives easier. Pickpockets were everywhere. Snatching food off food-vendor's carts and quickly running away, Oliver Twist under the criminal authority of Fagin is a perfect illustration.

\section{6- Neglect}

Many of the families who seek help for their children, or about whom others raise concerns about a child's welfare, are multiply disadvantaged. These families may face chronic poverty, social isolation, racism and the problems associated with living in disadvantaged areas, such as high crime, poor housing, childcare, transport and education services, and limited employment opportunities. Many lack a wage earner. Poverty may mean that children live in crowded or unsuitable accommodation, have poor diets, health problems or disability, are vulnerable to accidents, and lack ready access to good educational and leisure opportunities.

Racism and racial harassment is an additional source of stress for some families and children. Social exclusion can also have an indirect effect on children through its association with parental depression, learning disability, and long term physical health problems.

\section{7- Disabilities of parents.}

Being without shelter, or parents, wasn't unusual. Parents were often unable to support their offspring. These children would be turned out into the streets to fend for themselves. Child abuse was a common occurrence, so many children would just run away, and this was often the only method of getting something to eat.

If there was shelter, it was often in a tenement. These buildings would be filled with people of all ages, most often sharing single rooms. Disease was prevalent in these slum conditions due to the populations of fleas and rats. Sanitation was unheard of, and running water was a luxury few could experience. Water would come from an outside ditch. It was normal for these to be filled with raw sewage and dead animals.

By the late 1800's, it was widely felt that something needed to be done to help the poor. Homes were opened to help the youngsters who were roaming the streets. Laws governing the employment of children went onto the statute books. Moreover Mental illness in a parent or carer does not necessarily have an adverse impact on a child, but it is essential always to assess its implications for any children involved in the family. Parental 
illness may markedly restrict children's social and recreational activities. With both mental and physical illness in a parent, children may have caring responsibilities placed upon them inappropriate to their years, leading them to be worried and anxious. If they are depressed, parents may neglect their own and their children's physical and emotional needs. In some circumstances, some forms of mental illness may blunt parents' emotions and feelings, or cause them to behave towards their children in bizarre or violent ways. Unusually, but at the extreme, a child may be at risk of severe injury, profound neglect, or even death. child deaths where abuse and neglect had been a factor in the death, are a clear evidence of parental mental illness in one third of cases. In addition, postnatal depression can also be linked to both behavioural and physiological problems in the infants of such mothers.

\section{Conclusion}

This article has demonstrated that Charles Dickens works depict the squalid conditions the industrial revolution forced British children in, and has proved that adverse effects on children are less drastic when parental problems are not associated with family disharmony, and do not result in the family breaking up. Children may also be protected when the other parent or a family member can help respond to the child's needs. Children most at risk of significant harm are those who feature within parental delusions, and children who become targets for parental aggression or rejection, or who are neglected as a result of parental mental illness. Thanks to the involvement English writers and social activists in the struggle against abuse and neglect of children, a start of solution had been made. Nevertheless the lifestyle of destitute Victorian children did not see any major improvement until the early 1900 's.

\section{Bibliography}

[1] 1-Dickens, Charles. Oliver Twist. London, England: Richard Bentley, 1837.1

[2] 2- Dickens, Charles. David Copperfield. London, England: Bradbury and Evans, 1849.

[3] 3-Bender, David. Readings on Charles Dickens. San Diego, California. The Green haven Press, 1998.
[4] 4-Bloom, Harold. Charles Dickens. New York: Chelsea House Publishers, 1987.

[5] 5-Champion, Neil. Charles Dickens. Chicago, Illinois. Heinemann Library, 2002.

[6] 6-Chesterton, G.K. Appreciations and criticism of Charles Dickens. http://www.dickens.literature.com, 2009

[7] 7-Dafoe Daniel. History of the Devil, Michael Roe, http://.pgdp.net. Posted in 2009.

[8] 8-Dolin, Tim. George Eliot. (Oxford: Oxford University Press, 2005), p. 46

[9] 9-Graham Eleanor. The Story of Charles Dickens, New York, Abelard-Schuman, Inc. New York, 1954.

[10] 10-Harland, Nelson. Charles Dickens. Boston, Massachusetts: Twayne Publishers A division of G.K Hall \& CO, Norman. 1989.

[11] 11-Jedrzejewski, Jan. George Eliot. (New York: Routledge, 2007), p. 49

[12] 12- Kaplan, Fred. Dickens: A Biography. Baltimore, Maryland. The John Hopkins University. 1988

[13] 13-Larzelere Robert E.. A Comparison of Two Recent Reviews of Scientific Studies of Physical Punishment by Parents. Unpublished document posted at http://people.biola.edu/faculty/paulp/Larzelere02.html

[14] 14-Litvak, Joseph. Caught in the Act: Theatricality in the Nineteenth-Century English Novel University of California Press, 1992.

[15] 15-Logan, Peter Melville. George Eliot and the fetish of realism: Studies in the Literary Imagination, 2002.

[16] 16-Mitchell, Sally. Daily Life in Victorian England. Westport, Conn: Greenwood Press, 1996.

[17] 1-7Newsom, Robert. Fictions of Childhood. The Cambridge Companion to Charles Dickens. Ed. John O. Jordan. New York: Cambridge University Press, 2001.

[18] 18-Paul Schlicke. Oxford Reader's Companion to Dickens, Oxford: Oxford University Press, 1999.

[19] 19-Smiley, Jane. Charles Dickens. New York: A Lipper/ Viking Book, 2002.

[20] 20-Watson, J. B. Psychological care of infant and child. New York: W. W. Norton \& Co. 1928. 